\title{
DEVELOPMENT OF UNEMPLOYMENT IN SLOVAKIA IN THE CONTEXT OF THE COVID- 19 PANDEMIC
}

\author{
Lucia Svabova ${ }^{1, a, *}, Z^{2}$ denko Metzker ${ }^{2, b}$ and Tomasz Pisula ${ }^{3, c}$ \\ ${ }^{1}$ Faculty of Operation and Economics of Transport and Communications, Department of Economics, \\ University of Zilina, Univerzitna 1, 01026 Zilina, Slovak Republic \\ ${ }^{2}$ Center for Applied Economic Research, Faculty of Management and Economics, Tomas Bata \\ University in Zlin, Mostni 5139, 76001 Zlin, Czech Republic \\ ${ }^{3}$ Department of Quantitative Methods, The Faculty of Management, Rzeszow University of \\ Technology, al. Postancow W-wy 10, 35-959 Rzeszow, Poland \\ alucia.svabova@fpedas.uniza.sk, ${ }^{b}$ zoltan.rozsa@tnuni.sk, ${ }^{c}$ metzker@utb.cz, ${ }^{d}$ tpisula@ prz.edu.pl \\ ${ }^{*}$ Corresponding author
}

Cite as: Svabova, L., Metzker, Z., Tomasz, P. (2020). Development of unemployment in Slovakia in the context of the COVID-19 pandemic, Ekonomicko-manazerske spektrum, 14(2), 114-123.

Available at: dx.doi.org/10.26552/ems.2020.2.114-123.

Received: 23 September 2020; Received in revised form: 13 November 2020; Accepted: 22 November 2020; Available online: 2 December 2020

\begin{abstract}
The Covid-19 pandemic has affected all areas of our lives. The non-pharmaceutical anti-pandemic measures taken by the governments of the countries to reduce the number of people infected or reverse adverse developments also have a strong impact on the economic side of citizens' lives. The shutdown measures put an end to the activities of many entrepreneurs, who had to lay off their employees. Thus, the Covid-19 pandemic is a major reason behind the rising unemployment. This is also the case in Slovakia. Since March 2020, when the first measures came into force, the registered unemployment rate has been rising. The highest inflow of new jobseekers occurred in April 2020. In this article, we discuss development of the unemployment rate and of the numbers of newly registered jobseekers in Slovakia during the period from November 2019 to October 2020 and examine in more detail the impact of the shutdown measures on the development of the number of jobseekers in Slovakia and on the individual economic sectors according to the NACE classification. It was confirmed that these measures had the greatest impact on the sectors that are also the most publicized, such as the accommodation and food service industry, real estate, administrative and support service industry, arts, entertainment and recreation and other service industries. In these sectors, the number of new unemployment claims increased several times, especially in April 2020, and in some of them, the rate of the new unemployment claims has not returned to last year's values or those from the beginning of 2020.
\end{abstract}

Keywords: unemployment, jobseeker, COVID-19 pandemic, anti-pandemic measures

JEL Classification: J21, J64

\section{Introduction}

In March 2020, the Government of the Slovak Republic implemented the first strong antipandemic shutdown measures almost immediately following the identification of the first 
Covid-19 positive individuals in the country. This was during the first wave of the pandemic and the government was trying to mitigate the threat of a high number of infected individuals. These anti-pandemic shutdown measures included, for example, closing of all schools and shops except for grocery stores, drugstores, and pharmacies, but also the operation of bars, hotels, fitness centers, sports clubs, services, etc., similarly to the rest of Europe. Any mass events, even outdoor ones, have been cancelled and banned. These measures had a significant impact on the owners of these businesses and their employees. Especially smaller employers were unable to keep up and were therefore forced to lay off their staff. During the summer of 2020, the measures were gradually relaxed or repealed, but approximately from September onwards, the number of diagnosed Covid-19 infections gradually began to increase and the government reintroduced anti-pandemic measures to reverse the undesirable development. Employers and entrepreneurs have suffered losses again, which is still reflected in their deteriorating financial situation and the high number of unemployed people. (Laffineur et al., 2017)

The article aims to analyze the numbers of unemployed jobseekers and their development during the reference period between November 2019-October 2020, the twelve months preceding to the writing of this study. In the first three months of the year 2020, the pandemic did not have an impact yet, but since then the number of unemployed has increased. In this article, we want to point out the impact of government anti-pandemic measures and the pandemic itself on the development of the number of unemployed jobseekers in Slovakia and to identify those sectors of economic activities in which the number of unemployed has increased the most and can therefore be identified as those most affected by the Covid-19 pandemic.

The rest of the article is organized as follows. The literature review highlights the current situation of the studies on the impact of the Covid-19 pandemic on unemployment in other countries of the world. In the methodology and data section, we describe the origin of the data on which the analysis is based and mention the methods of the analysis. In the results section, we present the results of the analysis. In the following chapter, we discuss the results obtained and suggest a possible further direction for study. The last part concludes the article.

\section{$1.1 \quad$ Literature review}

Similar measures as in Slovakia were introduced in the surrounding countries. The sectors we identified as the most affected by the pandemic, are problematic not only in Slovakia but also in the neighboring Czech Republic and other European countries. In their studies, several authors focused on the issue of the effects of a pandemic on employment in different countries.

Almeida and Santos (2020) deal with the main impacts of Covid-19 on the labor market in Portugal. The authors found that the impact of the pandemic and measures against it in Portugal was asymmetric with regard to regions, age groups but also sectors of activities. The authors identified the most affected areas of the country, but also the individuals whose employment was most affected by the pandemic. They also discuss measures to mitigate the effects of the pandemic on employment in Portugal. (Mitra and Xu, 2020)

Kong and Prinz (2020) addressed how shutdown policies affected unemployment during the Covid-19 pandemic in the USA. They focused on the effects of six policies of nonpharmaceutical intervention and analyzed how Google searches for claiming unemployment responded to each policy. The authors provided estimates of the short-run impact of state-level anti-pandemic measures announcements on unemployment expectations, based on internet search data. 
In a study by Bauer and Weber (2020), the authors examined the real impact of antipandemic measures on unemployment in Germany. They used the difference-in-differences method where they compared the development of inflows to unemployment and quantified the $60 \%$ increase in unemployment due to the shutdown measures. In addition, they found that the hiring margin accounted for additional $82 \%$ of the unemployment effect coming from the separations margin. Overall, the authors quantified an increase in the number of unemployed in Germany due to the pandemic at 117,000 persons.

Chan et al. (2020) in their study focused on the analysis of employability of people with disabilities in the context of the Covid-19 pandemic. Using questionnaires obtained from the University of Wisconsin-Madison from employers in various industries, they examined the relationship between company characteristics, disability inclusion practices, and employment of people with disabilities.

In his study, Churchill (2020) examined the effects of the pandemic on youth employment in Australia. Using data from the Australian Bureau of Statistics, the author compared young men and women with their older counterfactuals and examined the unemployment rates of men and women in different age categories in 2000, during 2008 and then in the individual months of 2020. The author found that young people did not avoid the negative impact of the pandemic on employment, either, and their unemployment rate also increased significantly.

The issue of the Covid-19 unemployment pandemic is also mentioned in studies by other authors, such as Achdut and Refaeli (2020); Alhambra (2020); Al-Thaqeb et al. (2020); Autin et al. (2020); Dias et al. (2020); Forsythe et al. (2020); Hendrickx et al. (2020); Hensher (2020); Kantova and Arltova (2020); Mangan (2020a); Mangan (2020b); McGann et al. (2020); Parola (2020); Rosen and Stenbeck (2020); Sachs (2020); Sprague et al. (2020); Trzebiatowski et al. (2020).

In Slovakia, authors have not yet processed the impact of non-pharmaceutical anti-pandemic measures on unemployment in their scientific studies. The situation is similar in the neighboring Czech Republic.

\section{Methodology and Data}

In this study, we provide an analysis of the development of the number of unemployed individuals during the year 2020, examining both the total unemployment rate and the development in individual sectors of economic activity according to the NACE classification. When examining the development of the number of unemployed, we focused on their total number, but also on the monthly inflow of unemployed during the individual months of 2020 . Focusing in more detail on individual sectors of economic activities, we examined the total numbers of unemployed but also the inflow of new jobseekers during 2020.

The data for this analysis come from the monthly statistics on the unemployment rate, provided by the Center for Labor, Social Affairs and Family of the Slovak Republic (COLSAF). These are detailed statistics on the number of unemployed in individual cities of the Slovak Republic, in individual sectors of the economy, for various levels of education and both genders. In these monthly reports, the COLSAF specifies the monthly inflows and outflows of unemployed, while also listing the details on their handicaps, age categories, last jobs before registration in the jobseekers' database, duration of their unemployment or participation in programs of the active labor market policy.

We analyzed the obtained data on the development of the number of unemployed from a spatial and temporal point of view. To make the situation comparable, we used a calculation of basic indices of a time series, expressing the ratio of the inflow of jobseekers in a given month 
of the observed period to the selected base month. As base periods, we used November 2019 (the beginning of the observed period), but also January 2020 (because the numbers of unemployed were already higher then, but not yet due to the pandemic) and then computed the monthly basic indices of numbers of newly registered jobseekers.

\section{Results}

Figure 1 shows the inflow and outflow of the number of unemployed individuals from October 2019 to October 2020.

Figure 1: Monthly inflow and outflow of unemployed

inflow outflow

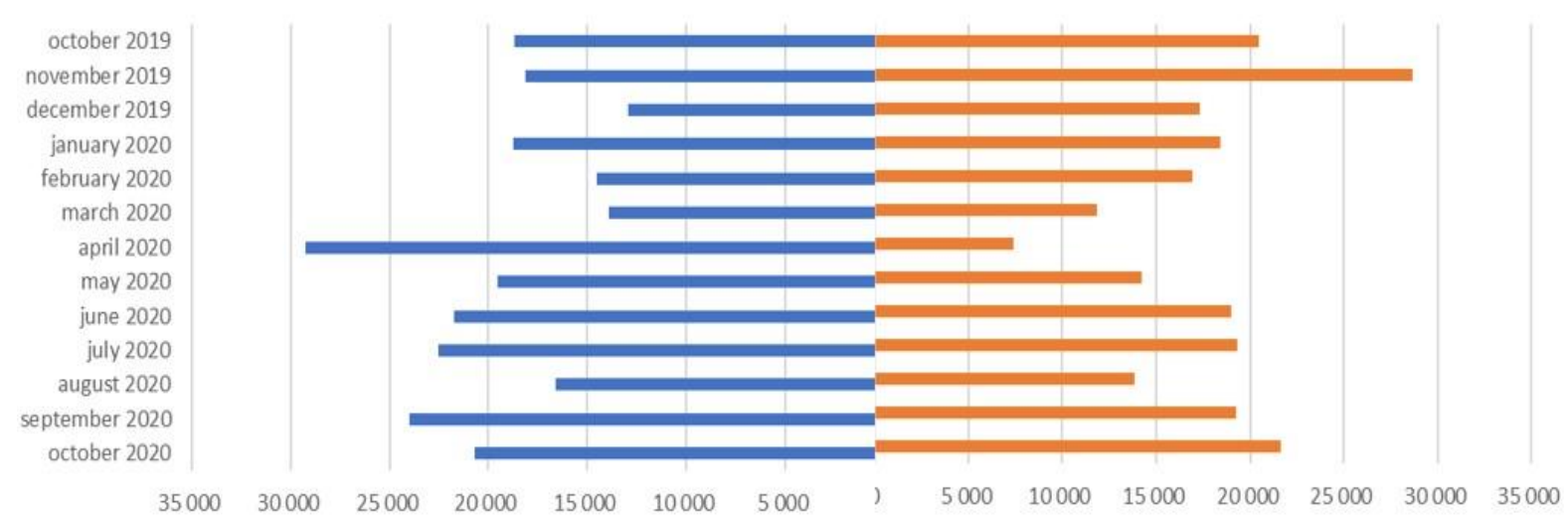

The difference between the inflow and outflow of unemployed individuals together with the development of the unemployment rate is shown in Figure 2.

Figure 2: Monthly change in the number of unemployed and the unemployment rate

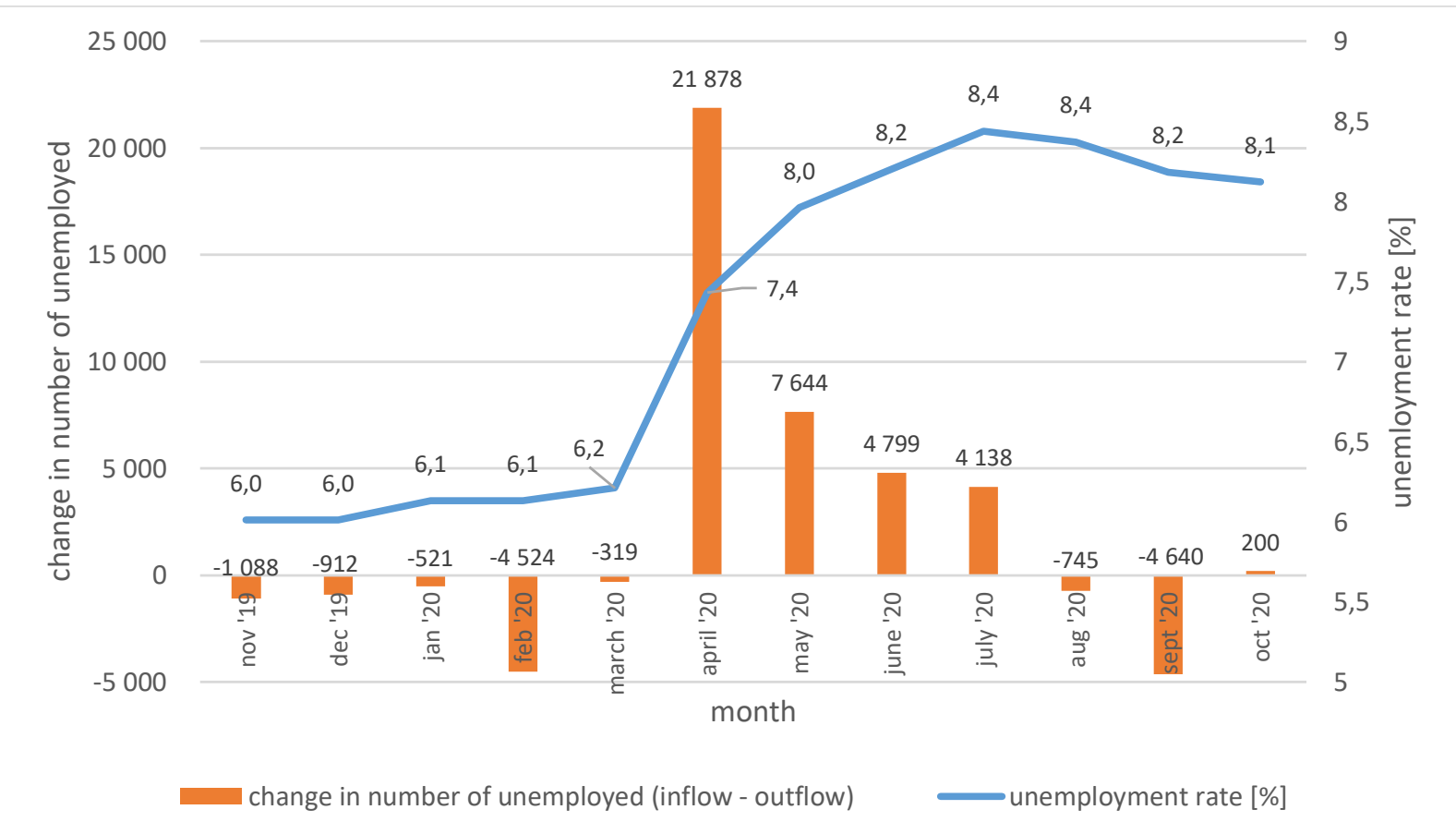


Development of unemployment in Slovakia in the context of the COVID-19 pandemic Authors: Lucia Svabova, Zdenko Metzker,

Tomasz Pisula

These two figures suggest that the development of the number of unemployed mirrored the development of the measures that were introduced in Slovakia due to the pandemic. The highest number of new unemployment claims, but also the highest increase, was recorded in April 2020, after the first strict government measures came into force in March 2020, including the closing of all businesses. In addition, the functioning of several manufacturing companies cooperating with foreign countries (import or export) was restricted. As pandemic measures were introduced in other countries as well, several manufacturing companies abroad did not operate or operated in a restricted regime. This led, for example, to a decrease in the volume of orders, therefore Slovak companies had to reduce production as well, with some of them also laying off employees.

The numbers gradually decreased towards the summer period, when the measures were modest and, for example, no markets were closed by government order. The situation was best in August 2020. It started to change again in the autumn of 2020 when new strict measures were introduced starting from September, which again had an impact on the unfavorable development of the unemployment rate. Newer data have not yet been published, but it can be assumed that the development will continue with the same or similar trend.

It is also important to focus on individual sectors of the economy and the impact of the pandemic and government measures on the number of unemployed in them in the studied period. Specifically, we monitored the inflow of new unemployment claims during the period under review according to the last profession they performed before being registered in the jobseeker database.

Figure 3: Inflow of newly registered jobseekers in NACE categories

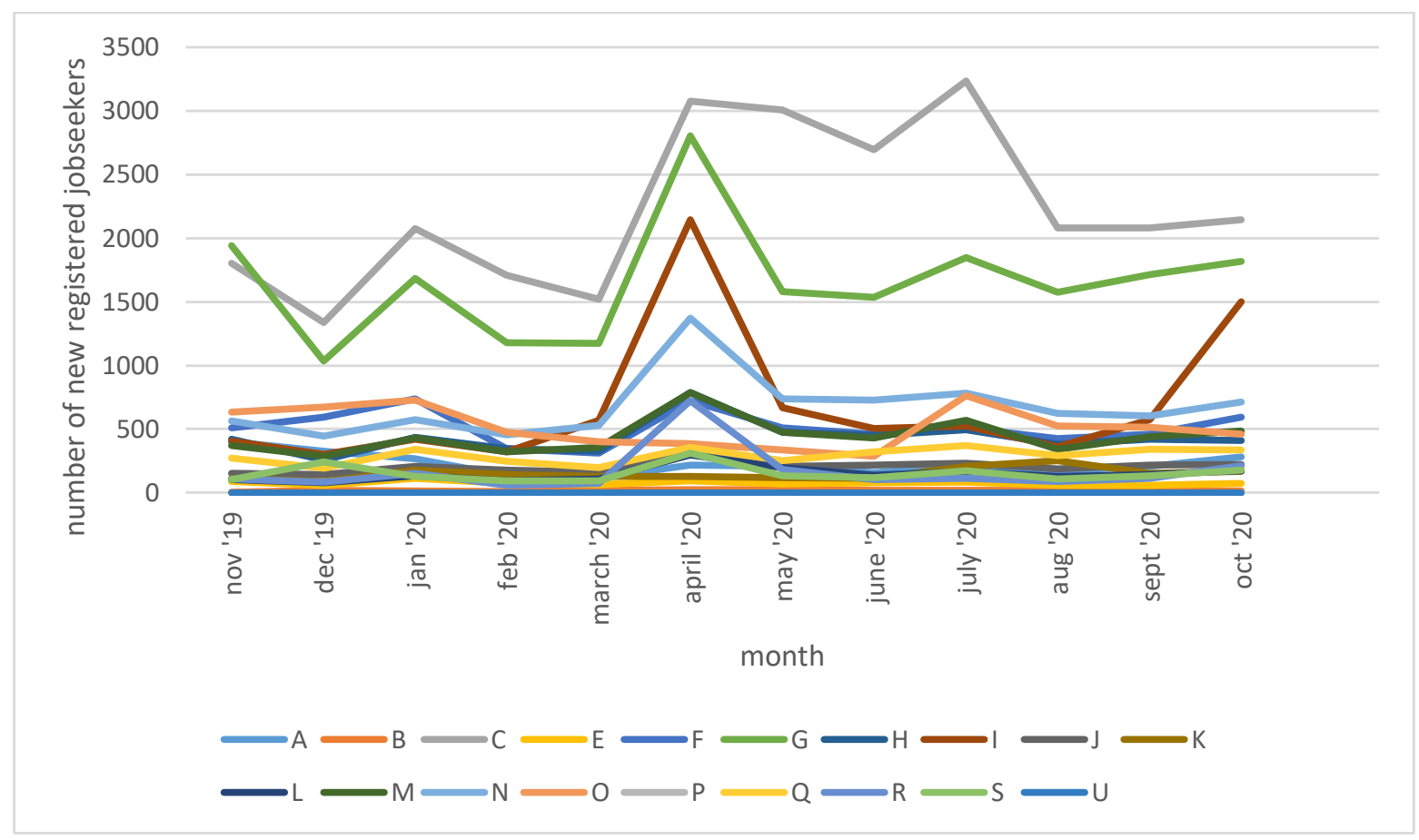

In April 2020, there was a significant increase in the number of unemployed in almost all areas, exceeding all other months of the reference period (except the NACE P-Education, where the highest increase was in July 2020, but for this sector it is relatively common for the number of unemployed to increase during the summer period). In some sectors, the situation has gradually stabilized, but in others, the number of newly registered jobseekers has remained significantly higher than in the pre-pandemic period. 
We also focused in more detail on the identification of those NACE sectors, in which the increase in the number of unemployed was the highest. Using the base indices, we have identified those NACE sectors of economic activities, in which the number of new jobseekers has increased several times since March 2020 - following in both cases the first anti-pandemic government measures, with the base periods in November 2019 and in January 2020. The numbers of jobseeker inflows in the most affected NACE sectors identified in this way can be found in Table 1.

Table 1: Categories of economic activities with the highest number of new jobseekers

\begin{tabular}{|c|c|c|c|c|c|c|c|c|c|c|c|c|c|}
\hline NACE code & Category & $\begin{array}{c}\text { nov } \\
\mathbf{1 9}\end{array}$ & $\begin{array}{c}\text { dec } \\
\mathbf{1 9}\end{array}$ & $\begin{array}{c}\text { jan } \\
\mathbf{2 0}\end{array}$ & $\begin{array}{c}\text { feb } \\
\mathbf{2 0}\end{array}$ & $\begin{array}{c}\mathbf{m a r c} \\
\mathbf{h} \mathbf{2 0}\end{array}$ & $\begin{array}{c}\text { april } \\
\mathbf{2 0}\end{array}$ & $\begin{array}{c}\text { may } \\
\mathbf{2 0}\end{array}$ & $\begin{array}{c}\text { june } \\
\mathbf{2 0}\end{array}$ & $\begin{array}{c}\text { july } \\
\mathbf{2 0}\end{array}$ & $\begin{array}{c}\text { aug } \\
\mathbf{2 0}\end{array}$ & $\begin{array}{c}\text { sept } \\
\mathbf{2 0}\end{array}$ & $\begin{array}{c}\text { oct } \\
\mathbf{2 0}\end{array}$ \\
\hline $\mathrm{I}$ & $\begin{array}{c}\text { Accommodation and } \\
\text { food service activities }\end{array}$ & 407 & 304 & 420 & 323 & 569 & 2146 & 670 & 504 & 523 & 363 & 573 & 1498 \\
\hline $\mathrm{L}$ & Real estate activities & 102 & 79 & 131 & 95 & 110 & 295 & 196 & 136 & 166 & 127 & 142 & 173 \\
\hline $\mathrm{N}$ & $\begin{array}{c}\text { Administrative and } \\
\text { support service } \\
\text { activities }\end{array}$ & 56 & 445 & 575 & 457 & 532 & 1372 & 737 & 729 & 780 & 622 & 605 & 713 \\
\hline $\mathrm{P}$ & Education & 210 & 137 & 226 & 247 & 161 & 275 & 202 & 186 & 1367 & 443 & 503 & 276 \\
\hline $\mathrm{R}$ & $\begin{array}{c}\text { Arts, entertainment } \\
\text { and recreation }\end{array}$ & 111 & 82 & 153 & 59 & 76 & 724 & 185 & 104 & 116 & 89 & 112 & 211 \\
\hline $\mathrm{S}$ & $\begin{array}{c}\text { Other service } \\
\text { activities }\end{array}$ & 102 & 241 & 129 & 93 & 95 & 313 & 131 & 120 & 173 & 108 & 132 & 179 \\
\hline
\end{tabular}

Source: Own elaboration

Table 2 lists the basic indices showing the ratio of newly registered jobseekers during the reference period in these selected NACE sectors. 
Development of unemployment in Slovakia in the context of the COVID-19 pandemic Authors: Lucia Svabova, Zdenko Metzker,

Tomasz Pisula

Table 2: Base indices of the number of new jobseekers

\begin{tabular}{|c|c|c|c|c|c|c|c|c|c|c|c|c|c|c|}
\hline NACE code & Category & Base period & $\begin{array}{l}\text { nov } \\
\text { '19 } \\
\end{array}$ & $\begin{array}{l}\text { dec } \\
\text { '19 } \\
\end{array}$ & $\begin{array}{l}\text { jan } \\
20 \\
\end{array}$ & $\begin{array}{l}\text { feb } \\
' 20 \\
\end{array}$ & $\begin{array}{l}\operatorname{marc} \\
\mathrm{h} ' 20\end{array}$ & $\begin{array}{c}\text { april } \\
20 \\
\end{array}$ & $\begin{array}{c}\text { may } \\
' 20 \\
\end{array}$ & $\begin{array}{c}\text { june } \\
\text { '20 } \\
\end{array}$ & $\begin{array}{l}\text { july } \\
\text { '20 } \\
\end{array}$ & $\begin{array}{l}\text { aug } \\
20 \\
\end{array}$ & $\begin{array}{c}\text { sept } \\
20 \\
\end{array}$ & $\begin{array}{l}\text { oct } \\
\text { '20 } \\
\end{array}$ \\
\hline \multirow{2}{*}{ I } & \multirow{2}{*}{$\begin{array}{c}\text { Accommodation } \\
\text { and food service } \\
\text { activities }\end{array}$} & jan '20 & 0,97 & 0,72 & 1,00 & 0,77 & 1,35 & 5,11 & 1,60 & 1,20 & 1,25 & 0,86 & 1,36 & 3,57 \\
\hline & & nov '19 & 1,00 & 0,75 & 1,03 & 0,79 & 1,40 & 5,27 & 1,65 & 1,24 & 1,29 & 0,89 & 1,41 & 3,68 \\
\hline \multirow{2}{*}{$\mathrm{L}$} & \multirow{2}{*}{$\begin{array}{l}\text { Real estate } \\
\text { activities }\end{array}$} & jan '20 & 0,78 & 0,60 & 1,00 & 0,73 & 0,84 & 2,25 & 1,50 & 1,04 & 1,27 & 0,97 & 1,08 & 1,32 \\
\hline & & nov '19 & 1,00 & 0,77 & 1,28 & 0,93 & 1,08 & 2,89 & 1,92 & 1,33 & 1,63 & 1,25 & 1,39 & 1,70 \\
\hline \multirow{2}{*}{$\mathrm{N}$} & \multirow{2}{*}{$\begin{array}{l}\text { Administrative } \\
\text { and support } \\
\text { service activities }\end{array}$} & jan '20 & 0,98 & 0,77 & 1,00 & 0,79 & 0,93 & 2,39 & 1,28 & 1,27 & 1,36 & 1,08 & 1,05 & 1,24 \\
\hline & & nov '19 & 1,00 & 0,79 & 1,02 & 0,81 & 0,94 & 2,43 & 1,31 & 1,29 & 1,38 & 1,10 & 1,07 & 1,26 \\
\hline \multirow{2}{*}{$P$} & \multirow{2}{*}{ Education } & jan '20 & 0,93 & 0,61 & 1,00 & 1,09 & 0,71 & 1,22 & 0,89 & 0,82 & 6,05 & 1,96 & 2,23 & 1,22 \\
\hline & & nov '19 & 1,00 & 0,65 & 1,08 & 1,18 & 0,77 & 1,31 & 0,96 & 0,89 & 6,51 & 2,11 & 2,40 & 1,31 \\
\hline \multirow{2}{*}{$\mathrm{R}$} & \multirow{2}{*}{$\begin{array}{l}\text { Arts, } \\
\text { entertainment and } \\
\text { recreation }\end{array}$} & jan '20 & 0,73 & 0,54 & 1,00 & 0,39 & 0,50 & 4,73 & 1,21 & 0,68 & 0,76 & 0,58 & 0,73 & 1,38 \\
\hline & & nov '19 & 1,00 & 0,74 & 1,38 & 0,53 & 0,68 & 6,52 & 1,67 & 0,94 & 1,05 & 0,80 & 1,01 & 1,90 \\
\hline \multirow{2}{*}{$S$} & \multirow{2}{*}{$\begin{array}{c}\text { Other service } \\
\text { activities }\end{array}$} & jan '20 & 0,79 & 1,87 & 1,00 & 0,72 & 0,74 & 2,43 & 1,02 & 0,93 & 1,34 & 0,84 & 1,02 & 1,39 \\
\hline & & nov'19 & 1,00 & 2,36 & 1,26 & 0,91 & 0,93 & 3,07 & 1,28 & 1,18 & 1,70 & 1,06 & 1,29 & 1,75 \\
\hline
\end{tabular}

Source: Own elaboration

The periods in which the highest base index indicated a more than twofold (or almost twofold) increase in the number of new jobseekers compared to the base month are marked in red.

\section{Discussion}

The anti-pandemic measures were introduced in Slovakia almost immediately after the discovery of the first Covid-19 cases in March 2020 and were very strict in this first wave of the pandemic. All shops, establishments, and services were closed, school facilities were closed, mass events were banned, etc. However, in the time gap between follow-up relief interventions were implemented to mitigate the effects of the anti-pandemic measures and to compensate companies, employers were unable to retain their employees and started laying them off, increasing the inflow of new unemployment claims. The situation was repeated, albeit in a milder form, in autumn 2020 after a resurgence of infections, when restrictive anti-pandemic measures were reintroduced. At the end of October 2020, the unemployment rate in Slovakia reached the level of $8.2 \%$ and the number of jobseekers was 222,242 compared to 168,757 jobseekers in January of the same year. The Statistical Office of the Slovak Republic states that the impact of the Covid-19 crisis was manifested mainly by a rapid increase in the rates of frictional (up to one month) and short-term (one to three months) unemployment and their share 
in the total unemployment rate. In summary, the number of persons in these two groups in the structure of the unemployed doubled year-on-year.

For all the most affected selected sectors of economic activity, the immediate impact of the anti-pandemic measures clearly occurred in April 2020. In Table 2, it was expressed by the ratio of the number of new unemployment claims to the base period, and in this case, it does not matter whether it was the beginning of the reference period or the beginning of 2020. The only exception is the sector NACE P - Education. This sector recorded an increase in the number of new jobseekers mainly in July 2020 (6.51 multiple of the number of new jobseekers from November 2019 and 6.05 multiple of the number in January 2020). Compared to both base months, the numbers were also increased in August and September of this year. However, we believe that this increase was mainly due to seasonal unemployment, as in some school facilities it is a common practice for teachers to have employment contracts only for the ten school year months (September-June). These schools usually terminate such contracts at the start of the summer vacation period. Therefore, we assume that the sector is not heavily affected by the Covid-19 coronavirus pandemic, although we have listed it according to the base indices in Tables 1 and 2, as they were among the highest for both base periods.

In category I - Accommodation and food service activities, the introduction of measures in March 2020 resulted in a high increase in the number of unemployed to 5.27 multiple of the number from November 2019 and up to 5.11 multiple of the number of new unemployment claims from January 2020. These numbers dropped to the level of the pre-pandemic period only in August 2020, when the measures were modest and most Slovaks decided to spend their vacations in Slovakia, which contributed to a temporary reduction in unemployment in this sector. In October of this year, there was again a high increase to 3.68 multiple of the number from November of the last year and 3.57 multiple of the number from January 2020. This development exactly mirrors the implemented anti-pandemic measures, which once again significantly limited the accommodation and food service industries. This sector is one of the most heavily affected by the pandemic and the anti-pandemic measures, which is reflected by the number in Table 1.

In category L - Real estate activities, the highest increase in the number of new unemployment claims also occurred in April 2020. Their number was up to 2.89 multiple of the number in October of the last year and 2.25 times higher than in January of this year. The situation relaxed in the following months, but has not returned to the level recorded at the beginning of the period under review. This sector is affected by the pandemic mainly because people are likely afraid of investing in real estate at a time when the stability of their income is uncertain. Category N - Administrative and support service activities recorded a 2.47 multiple increase in the number of new unemployment claims compared to the beginning of the period under review and a 2.39 multiple increase compared to the beginning of this year. The numbers have remained elevated throughout the following period. This area deserves closer analysis, as this category of economic activity includes, for example, Rental and leasing activities, which are likely in decline during the pandemic period, but also Employment activities, which could conversely see an increase in activity, and Travel agency activities, which are certainly heavily affected by the anti-pandemic measures. Sector R - Arts, entertainment, and recreation was also one of the most heavily affected by the pandemic in spring 2020, as activities of this type were completely restricted. This was reflected in an increase in the number of new unemployed claims within this profession to 6.52 multiple of the number from the beginning of the period under review, or 4.73 multiple of the number in January 2020. During the summer period, there was a significant improvement to about the level from the beginning of the period under review. In October 2020, with the introduction of new anti-pandemic measures, there was further 
Development of unemployment in Slovakia in the context of the COVID-19 pandemic Authors: Lucia Svabova, Zdenko Metzker,

Tomasz Pisula

deterioration, but the government provided a compensatory program for the sector and the situation calmed down. Category S - Other services includes, for example, personal service activities such as Hairdressing and other beauty treatment and others. These services were completely banned in the spring, which resulted in a threefold increase in the number of new jobseekers compared to the beginning of the period under review, or 2.43 times compared to the beginning of 2020. The situation improved from there, but the numbers of new unemployment claims remained higher than in November 2019.

The Covid-19 pandemic, but especially the anti-pandemic measures that must be implemented in Slovakia, much like in other countries, clearly have a significant impact on the country's employment rate. We therefore see the possibility of a follow-up on this study in the form of a rigorous assessment of the effects of the pandemic on unemployment in Slovakia, for example using methods of before-after comparison, taking into account a longer period before the crisis and analyzing the usual monthly development of the unemployment in Slovakia.

\section{Conclusion}

Based on analyses of the development of the unemployment rate and the inflow of newly registered jobseekers, we found that the development of the unemployment rate mirrors the period of anti-pandemic government measures, which limited or completely stopped the operation of some sectors. The measures have the highest impact on the unemployment in the following sectors: Accommodation and food service activities; Real estate activities; Administrative and support service activities; Arts, entertainment, and recreation; Other service activities. These sectors are accordingly most often referred in the Slovak media as being affected by the anti-pandemic measures. The Government of the Slovak Republic seeks to eliminate the effects of these measures by introducing interventions to help the businesses survive and provide at least partial compensation to employers so that they are able to retain their employees. Nevertheless, as can be seen from the results of the analysis, there is an increase in the number of unemployed in these sectors, and this increase is an almost immediate response to the measures in place.

\section{References}

Achdut, N., \& Refaeli, T. (2020). Unemployment and psychological distress among young people during the COVID-19 pandemic: Psychological resources and risk factors. International Journal of Environmental Research and Public Health, 17(19), 7163.

Alhambra, M. A. G.-M. (2020). Covid-19 and labour law in Spain. European Labour Law Journal, 11(3), 319323.

Almeida, F., \& Santos, J. D. (2020). The effects of COVID-19 on job security and unemployment in Portugal. International Journal of Sociology and Social Policy, Forthcoming Article (Early Access: Sep 2020).

Al-Thaqeb, S. A., Algharabali, B. G., \& Alabdulghafour, K. T. (2020). The pandemic and economic policy uncertainty. International Journal of Finance \& Economics, Forthcoming Article (Early Access: Oct 2020).

Autin, K. L., Blustein, D. L., Ali, S. R., \& Garriott, P. O. (2020). Career development impacts of COVID-19: Practice and policy recommendations. Journal of Career Development, 47(5), 487-494.

Bauer, A., \& Weber, E. (2020). COVID-19: How much unemployment was caused by the shutdown in Germany? Applied Economics Letters, Forthcoming Article (Early Access: Jul 2020).

Dias, M. C., Joyce, R., Postel-Vinay, F., \& Xu, X. (2020). The challenges for labour market policy during the COVID-19 pandemic. Fiscal Studies, 41(2), 371-382.

Forsythe, E., Kahn, L. B., Lange, F., \& Wiczer, D. G. (2020). Labor Demand in the time of COVID-19: Evidence from vacancy postings and UI claims (Č. w27061). National Bureau of Economic Research.

Hendrickx, F., Taes, S., \& Wouters, M. (2020). Covid-19 and labour law in Belgium. European Labour Law Journal, 11(3), 276-285.

Hensher, M. (2020). Covid-19, unemployment, and health: Time for deeper solutions? BMJ, m3687. 
Chan, F., Tansey, T. N., Iwanaga, K., Bezyak, J., Wehman, P., Phillips, B. N., Strauser, D. R., \& Anderson, C. (2020). Company characteristics, disability inclusion practices, and employment of people with disabilities in the post COVID-19 job economy: A cross sectional survey study. Journal of Occupational Rehabilitation, Forthcoming Article (Early Access: Nov 2020).

Churchill, B. (2020). COVID-19 and the immediate impact on young people and employment in Australia: A gendered analysis. Gender, Work \& Organization, Forthcoming Article (Early Access: Oct 2020).

Kantova, M., \& Arltova, M. (2020). Emerging from crisis: Sweden's active labour market policy and vulnerable groups. The Economic and Labour Relations Review, 31(4), 543-564.

Kong, E., \& Prinz, D. (2020). Disentangling policy effects using proxy data: Which shutdown policies affected unemployment during the COVID-19 pandemic? Journal of Public Economics, 189, 104257.

Laffineur, C., Barbosa, S. D., Fayolle, A. et al. (2017). Active labor market programs'effects on entrepreneurship and unemployment. Small Business Economics, 49(4), 889-918.

Mangan, D. (2020a). Covid-19 and labour law in Ireland. European Labour Law Journal, 11(3), 298-305.

Mangan, D. (2020b). Covid-19 and labour law in the United Kingdom. European Labour Law Journal, 11(3), 332-346.

McGann, M., Murphy, M. P., \& Whelan, N. (2020). Workfare redux? Pandemic unemployment, labour activation and the lessons of post-crisis welfare reform in Ireland. International Journal of Sociology and Social Policy, 40(9/10), 963-978.

Mitra, I., \& Xu, Y. (2020). Time-varying risk premium and unemployment risk across age groups. Review of Financial Studies, 33(8), 3624-3673.

Parola, A. (2020). Novel coronavirus outbreak and career development: A narrative approach into the meaning for italian university graduates. Frontiers in Psychology, 11, 2255.

Rosen, M., \& Stenbeck, M. (2020). Interventions to suppress the coronavirus pandemic will increase unemployment and lead to many premature deaths. Scandinavian Journal of Public Health, Forthcoming Article (Early Acess: Aug 2020), 1403494820947974.

Sachs, T. (2020). Covid-19 and labour law in France. European Labour Law Journal, 11(3), $286-291$. https://doi.org/10.1177/2031952520934565.

Sprague, A., Raub, A., \& Heymann, J. (2020). Providing a foundation for decent work and adequate income during health and economic crises: Constitutional approaches in 193 countries. International Journal of Sociology and Social Policy, 40(9/10), 1087-1105.

Trzebiatowski, T. M., Wanberg, C. R., \& Dossinger, K. (2020). Unemployed needn't apply: Unemployment status, legislation, and interview requests. Journal of Management, 46(8), 1380-1407. 